\title{
K.В. ШУРТАКОВ,
}

заместитель генерального директора, руководитель отдела информационно-аналитического и организационного обеспечения ФГБНУ «Дирекция НТП» Минобрнауки России,

г. Москва, Россия

\section{«ПАТЕНТНЫЕ ТРОЛЛИ»: АНАЛИЗ ЗАРУБЕЖНОЙ И РОССИЙСКОЙ ПРАКТИКИ}

УДК 004.031.4:001

Шуртаков К.В. «Патентные тролли»: анализ зарубежной и российской практики (ФГБНУ «Дирекция НТП»

1. Минобрнауки России, г. Москва, Россия)

I Аннотация. Представлен анализ зарубежной практики выявления и противодействия «патентному троллингу»

I как новому виду бизнеса, основанному на злоупотреблении патентными правами.

I Рассмотрены экономические параметры, определяющие размер возбуждаемых исков и отраслевые

особенности «патентного троллинга».

Ключевые слова: патентные тролли, патентные судебные споры, размер судебных исков, отраслевая патентная активноСть.

DOI 10.22394/2410-132X-2016-2-4-293-303
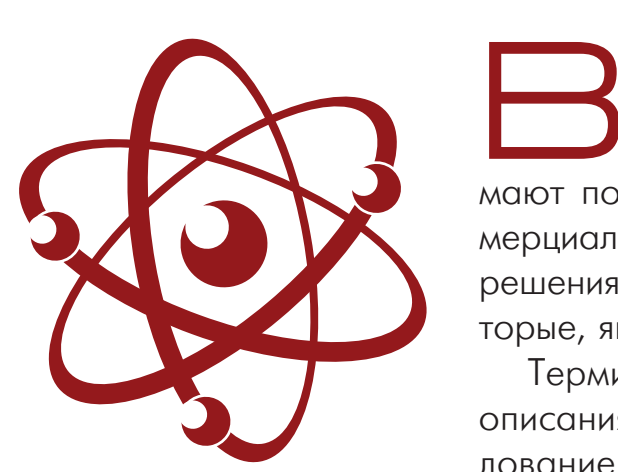

настоящее время в индустриально развитых странах все более широкое распространение получает практика, так называемого, «патентного троллинга», под которым понимают получение патента на изобретение не для дальнейшей коммерциализации и практического использования нового технического решения, а для предъявления исков к хозяйствующим субъектам, которые, якобы, незаконно используют запатентованную разработку.

Термин «патентный тролль» начали использовать с 1993 г. для описания компаний, агрессивно проводящих патентное преследование и желающих получать ренту с лицензионных отчислений [1]. В последствии эта метафора была популяризирована Питером Деткиным, работавшим в компании Intel [2], который описал этим термином действия компании TechSearch и её адвоката Раймонда Ниро по преследованию компании Intel [3].

Сегодня под патентным троллем понимают физическое или юридическое лицо, специализирующееся на предъявлении патентных исков. Сами же патентные тролли предпочитают называть себя патентными холдингами, патентными дилерами, непрактикующим лицом или непроизводящим патентовладельцем

Экономическим фундаментом этой бизнес-модели является сопоставимость размера лицензионных отчислений, которые требует патентный тролль и судебных издержек, которые несут ответчики. Например, Лаборатория Касперского дала отпор троллю, однако судебные издержки компании составили 2,5 млн долл. [4].

Действующее в различных странах законодательство сулит нарушителям патентов суровое наказание: обладатель патента может требовать пресечения действий, нарушающих его исключительные 
права, возмещения убытков, выплаты компенсаций и даже изъятия материальных ценностей у изготовителей, хранителей, перевозчиков и продавцов. Если дело дойдет до судебного разбирательства, может быть принято решение об изъятии и уничтожении оборудования, применявшегося при совершении нарушения. Кроме того, не исключено и уголовное преследование нарушителя. Например, в РФ незаконное использование изобретения, полезной модели или промышленного образца влечет штраф или лишение свободы на срок до двух лет в соответствии со ст. 147 УК РФ [5].

Анализ практики патентных споров показывает, что владея специальной терминологией, зная процедуру рассмотрения патентной заявки и нюансы, связанные с экспертной оценкой, можно получить патент на известное техническое решение. При этом признак, свойственный уже известной продукции или технологии, делается базовым отличительным признаком для некоего нового «изобретения». Риск таких манипуляций минимален (патент просто не будет получен), наказания за попытку запатентовать уже известное изобретение не предусмотрено (заявитель мог заблуждается относительно новизны предлагаемого решения), а потенциальный доход велик.

Первым резонансным случаем патентного троллинга в России стал опубликованный в 1999 г. патент РФ № 2139818 на изобретение «Сосуда стеклянного», описание которого полностью соответствует стеклянной бутылке. Авторами «изобретения» стали Калиниченко С.В., Торицын И.В., а патентообладателем - ООО «Технополис» [6]. Заявленная сущность изобретения была сформулирована следующим образом: «Задачей изобретения является создание стеклянного сосуда, обеспечивающего конструктивно заложенную форму и/или конструктивно заложенное изменение его толщины для облегчения процесса утилизации и/или использование в качестве конструктивного элемента».

Сразу же после получения патента ООО «Технополис» начал требовать от всех компаний, производящих пиво и безалкогольные напитки, лицензионных отчислений в размере не менее 0,5\% от выручки. Основания для та- ких выплат у «Технополиса» формально были: им принадлежал патент на техническое решение, которое на тот момент без разрешения использовали все производители жидкостей в стеклянной таре. По решению Палаты по патентным спора, вынесенному в 2000 г., патент был аннулирован.

Вторая резонансная история патентного троллинга в РФ связана с обладателем патентов РФ под номерами 2008102012, 74862, 74603 и 74602 с с общей датой приоритета от 27 декабря 2006 г. (патент на изобретение и три патента на полезные модели с общим названием «Амортизатор транспортного средства»). Патентообладатель Олег Тихоненко пытался получить с иностранных компаний-производителей автомобильных амортизаторов от 30 млн евро до 50 млн евро. В числе нарушителей патентных О. Тихоненко оказались: японская компания Kayaba (торговая марка KYB), немецкая компания ZF Trading (марки Sachs и Boge) и американская компания Gates (марка Bilstein). Патентообладатель обращался в отделы по экономическим преступлениям с целью остановить продажи контрафактных, по его мнению, амортизаторов, что ему удалось: был арестован склад одного из поставщиков. Несмотря на то что, по мнению экспертов, устройство амортизаторов О. Тихоненко было ранее описано в патенте США, а математическая формула, с помощью которой в патенте О. Тихоненко описано действие его улучшенных амортизаторов, взята из советского технического справочника, коллегия Палаты по патентным спорам смогла аннулировать патенты Тихоненко лишь в ноябре 2009 г. [7].

В 2016 г. в Палате по патентным спорам оспаривалась полезная модель «Подставка под зубочистки» и полезная модель «Держатель для метки циферблата настенных часов». По сути, речь идет о накрытых крышками коробках, но правообладатель, Александр Максимов, на имя которого зарегистрировано более 800 патентов РФ, в настоящее время судится с аптечными сетями по всей России, которые, якобы незаконно, используют его изобретения. Одна из крупных аптечных сетей уже оплатила штрафы, якобы за нарушение патента на «Держатель для циферблатов на- 
стенных часов», поскольку продавала настойку календулы в картонных коробках [8].

Не все патентообладатели мирятся с решением Палаты по патентным спорам, аннулирующим их патент на полезную модель. Иногда споры переносятся в суды, где лишенный патента пытается отстоять свое право на защиту, даже если его изобретение признано непатентопригодным как неоригинальное. В «Аналитической справке по результатам анализа судебной практики по вопросам, связанным с правовой охраной объектов интеллектуальной собственности» Роспатента за 2009 г. [9] есть такие примеры. По мнению авторов справки, сложность рассмотрения таких споров заключается в том, что суд сталкивается с необходимостью определить, какие из признаков формулы полезной модели являются существенными, а какие нет. Сделать такие выводы самостоятельно суды порой неспособны. В справке указывается, что в подобных судебных процесcax часто возникают вопросы, требующие знаний не только действующего законодательства, но и специальных познаний, а также практики патентной экспертизы, которыми действующие гражданские и арбитражные суды владеют слабо. Более того, по мнению специалистов Роспатента, «назначение судом при рассмотрении подобных дел технической и патентно-технической экспертиз не выглядит оправданным, поскольку в Российской Федерации отсутствуют специализированные организации, компетентные проводить такие исследования». Таким образом, по мнению составителей справки, «подобная практика не способствует объективному и всестороннему рассмотрению судами дел, связанных с правами на результаты интеллектуальной деятельности, поскольку экспертное заключение становится предопределяющим фактором при принятии решения» [10].

Случаи предъявления претензий, в основе которых лежит злоупотребление патентными правами, фиксируются в РФ все чаще и приобретают все более масштабный характер. Возникает бизнес, который подрывает основы патентного права и доверие к специалистам. Анализ зарубежной практики выявления и противодействия «патентному троллингу» стал целью настоящей статьи.

\section{ПАТЕНТЫЙ ТРОЛЛИНГ КАК БИЗНЕС}

Если для России столкновения с «патентными троллями»- относительно новое явление, то в странах с развитыми рыночными институтами это уже распространенная практика бизнеса и правоприменительная практика судебных споров. Обобщение такой практики опубликовано в докладе PricewaterhouseCoopers «Патентные споры в 2015 г.: изменение в судьбах обладателей патентных прав» [10].

В докладе «патентных троллей» называют «непрактикующими субъектами-патентообладателями» (далее НПС). По мнению авторов доклада, это - одна из наиболее актуальных проблем современной практики применения патентного права, которая оказывает очень серьезное экономическое, мировоззренческое и правовое влияние на многие сферы бизнеса и потребления. Установлено, что есть прямая связь между ростом активности тех, кто злоупотребляет своими патентными правами, и прямыми и косвенными потерями инновационных компаний. Такие компании и особенно стартапы чаще всего дают шанс проявить себя молодым изобретателям, которые разрабатывают новые неординарные технологии, создают рабочие места и поддерживают здоровую конкуренцию.

Согласно данным исследования, выполненного сотрудниками Бостонского университета в 2012 г., НПС сами никогда не используют запатентованную технологию для производства товаров и услуг, а вместо этого, злоупотребляя своими правами, ввергают компании, производящие товары и услуги с использованием технических решений, подпадающих под действие своих патентов, в разбирательства по судебным претензиям [11]. Именно благодаря их активности растет число судебных патентных споров и наиболее болезненно это для инновационных компаний, выводящих новую продукцию на рынок.

Обычно к числу НПС относят не только одиозных «патентных троллей», но и ряд иных организаций, в число которых входят университеты, индивидуальные заявители, иные организации, которые защищают свои патенты не в той сфере экономики, где они ведут ос- 
новную коммерческую деятельность. Причем, большинство из них и особенно университеты, как правило, не злоупотребляют своими патентными правами.

«Патентные тролли» не только причиняют убытки, но и лишают ценности основные принципы, лежащие в основе всего патентного права, из-за чего такие правовые нормы все чаще подвергается суровой критике. Действующие, но неиспользуемые патенты ограничивают проведение научных исследований и предпринимательскую инициативу, лишают собственных клиентов достаточного вознаграждения и устойчивых деловых связей. И, что самое главное, они переориентируют своих собственников на патентование массовых, общепонятных и, практически, стандартных технических решений, с минимальным изобретательским уровнем, поскольку именно такие патенты будут заимствоваться чаще всего и принесут агрессивным защитникам патентов наибольшую прибыль.

Одним из последних примеров «патентного троллинга» является иск компании VirnetX, уже хорошо известной как патентный тролль. VirnetX в очередной раз удалось доказать незаконное использование своих патентов сервисами iMessage и FaceTime, которые применяются компанией Apple. В результате рассмотрения иска, суд США обязал компанию Apple выплатить компании VirnetX 625 млн долл., что намного превышает итоговую сумму выплат Apple по последнему судебному процессу - тогда VirnetX смогла отсудить 368 млн долд. [12]. Основная часть дохода VirnetX приходится как раз на лицензирование патентов и судебные иски. Только за последнее десятилетие жертвой VirnetX стало сразу несколько крупных IT-компаний, среди которых оказались Cisco, Avaya, Siemens и Microsoft и ряд других. Так, в 2010 г. VirnetX смогла выиграть у Microsoft более $200 \mathrm{Mлн}$ долл. за незаконное использование патентов на VPN в Windows Server 2003, XP, Vista, Live Communication Server, Windows Messenger, Office Communication и некоторых версиях пакета Office. А в 2014 г. компания выиграла суд на 24 млн долл. у Microsoft за использование собственных патентов в Skype.
Согласно результатам исследования профессора MIT Кэтрин Такер, за прошедшее пятилетие вложения венчурных капиталистов в новые проекты могли бы быть на 21,772 млрд долл. выше, если бы не постоянные юридические претензии от патентных троллей [13]. K их числу автор исследования причислила все компании, которые владели, но не использовали 20 и более патентов за период с 1995 по 2012 гг. В исследовании Такер установлен 95\% уровень корреляции между активностью компаний, специализирующихся на патентных претензиях, и недополучением инвестиций в размере от 8,1 до 41,8 млрд долл. за пять лет. Более того, чем выше сумма инвестиций или интерес инвесторов к проекту, тем чаще подаются судебные иски и иные претензии по авторским правам и патентам. С определенного момента специализация исключительно на патентных претензиях приводит к потерям доверия инвесторов и сокращению вложений в тот или иной стартап. Даже если иск будет отклонен, потери стартапов связаны со снижением оценки бизнеса инвесторами, издержками от судебного разбирательства, необходимостью сокращения ряда сотрудников и пр.

\section{СТАТИСТИКА СУДЕБНЫХ СПОРОВ С «ПАТЕНТНЫМИ ТРОЛЛЯМИ》}

Неприятие практики злоупотребления патентным правом отражается на судебных решениях. Разница в размерах присужденного ущерба для НПС и практикующих субъектов растет. В докладе PricewaterhouseCoopers отмечается продолжение тенденции, которая началась в начале 2000-х гг.: значительно больший совокупный размер возмещения ущерба, присуждаемый для НПС относительно практикующих патентообладателей [10]. На рис. 1 показана разница между средним размером присуждаемого судами ущерба в исках по патентным спорам. Как видно по приведенным на рисунке данным, средний размер присужденного ущерба в пользу НПС по сравнению с практикующими патентообладателями вырос почти в 4,5 раза в текущем пятилетии.

Вместе с тем, общая доля успешных процессов для практикующих патентообладате- 
11,4

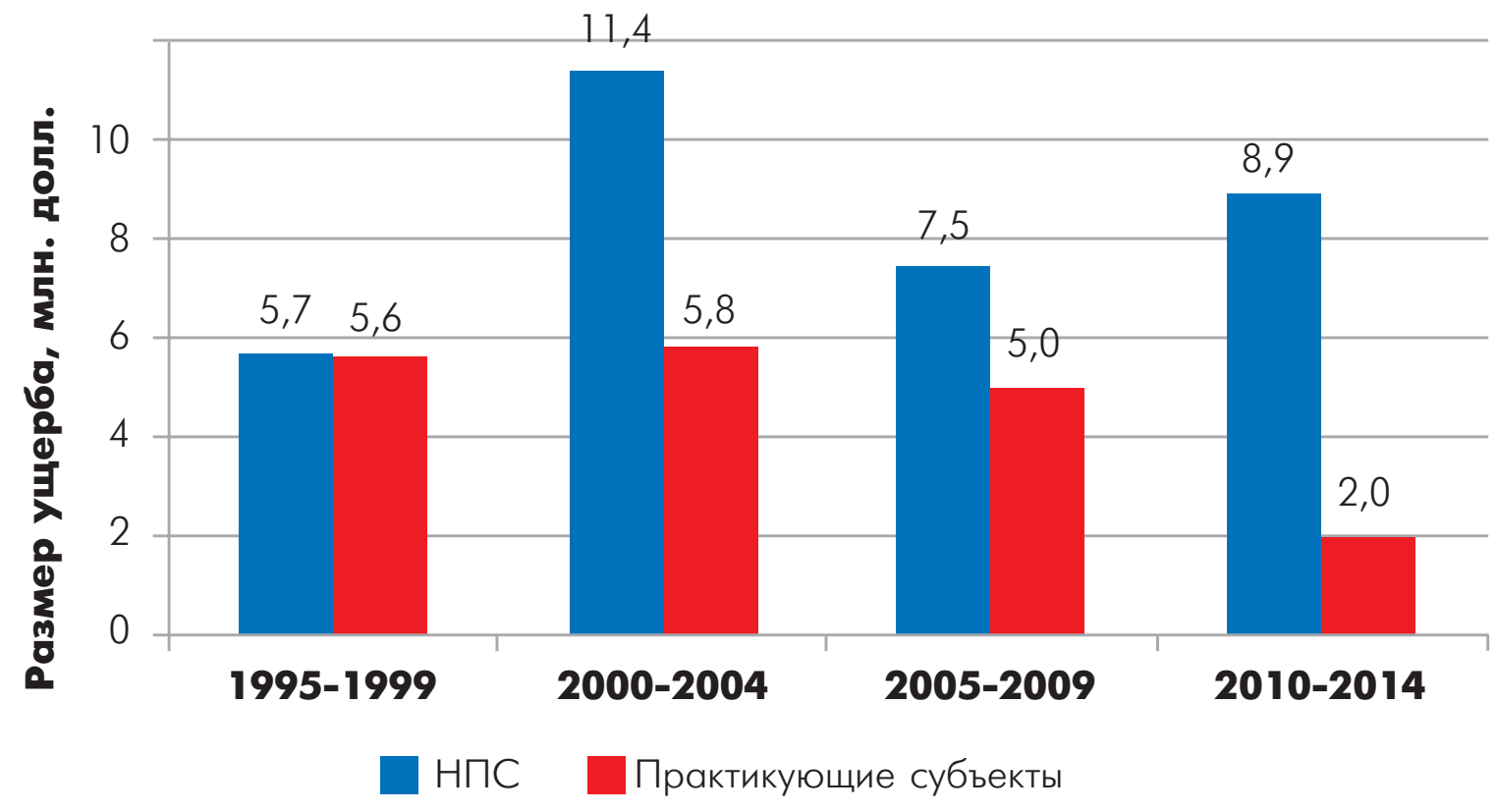

Рис. 1. Средний размер присужденного ущерба непрактикующих патентообладателей по сравнению с практикующими патентообладателями

Источник: 2015 Patent Litigation Study: A change in patentee fortunes

\section{Топ-10 самых крупных первоначально присужденных компенсаций ущерба, 1995-2014 rr.}

\begin{tabular}{|c|c|c|c|c|}
\hline Год & Истец & Ответчик & Технология & $\begin{array}{c}\text { Выплата } \\
\text { (млн долл.) }\end{array}$ \\
\hline 2009 & $\begin{array}{l}\text { Centocor Ortho Biotech } \\
\text { Inc. }\end{array}$ & Abbott Laboratories & Препараты от артрита & 1673 \\
\hline 2007 & Lucent Technologies Inc. & Microsoft Corp. & MP3 - технология & 1538 \\
\hline 2012 & $\begin{array}{l}\text { Carnegie Mellon } \\
\text { University }\end{array}$ & $\begin{array}{l}\text { Marvell Technology } \\
\text { Group }\end{array}$ & $\begin{array}{l}\text { Снижение уровня шума } \\
\text { на схемах для жестких } \\
\text { дисков }\end{array}$ & 1169 \\
\hline 2012 & Apple Inc. & Samsung Electronics Co. & $\begin{array}{l}\text { Программное обеспече- } \\
\text { ние для смартфонов }\end{array}$ & 1049 \\
\hline 2012 & Monsanto Company & $\begin{array}{l}\text { E. I. du Pont de Nemours } \\
\text { and Co. }\end{array}$ & $\begin{array}{l}\text { Генно-модифицирован- } \\
\text { ные семена сои }\end{array}$ & 1000 \\
\hline 2010 & Mirror Worlds LLC & Apple Inc. & Операционная система & 626 \\
\hline 2005 & Cordis Corp. & Medtronic Vascular. Inc. & Стенты для сосудов & 595 \\
\hline 2004 & Eolas Technologies Inc. & Microsoft Corp. & Интернет-браузер & 521 \\
\hline 2011 & Bruce N. Saffran, M.D. & Johnson \& Johnson & $\begin{array}{l}\text { Стенты с лекарственным } \\
\text { покрытием }\end{array}$ & 482 \\
\hline 2014 & Masimo Corporation & $\begin{array}{l}\text { Philips Electronics } \\
\text { N. America Corp. }\end{array}$ & $\begin{array}{l}\text { Прибор для измере- } \\
\text { ния уровня кислорода } \\
\text { в крови }\end{array}$ & 467 \\
\hline
\end{tabular}

Источник: 2015 Patent Litigation Study: A change in patentee fortunes 
лей почти на 10\% выше в течение последних 20 лет, чем для НПС. Средние размеры присужденного ущерба продолжают тенденцию к снижению.

Крупные суммы присужденных компенсаций ущерба (около и более 1 млрд долл.) обычно попадают в заголовки газет и становятся широко известными. В табл. 1 показан рейтинг топ-10 наиболее крупных размеров компенсаций за нарушение прав интеллектуальной собственности. С 2012 г. подобных случаев все меньше. Тем не менее, в 2014 г. наблюдался случай, вошедший в топ-10 Masimo Corporation против Phillips Electronics. Сумма возмещения ущерба по иску Masimo Corporation за технологию измерения уровня кислорода в крови составила 467 млн долл.

Среднегодовой размер присужденного ущерба в форме разумного роялти также продолжает тенденцию к снижению. Расчет разумных значений роялти вдвое чаще используют по сравнению с возмещением потерянной прибыли патентообладателя.

Есть несколько причин, по которым компенсация потерянной прибыли присуждается не так часто, как разумные лицензионные платежи. Во-первых, патентообладатель зачастую склонен избегать претензий по случаю упущенной выгоды, не желая рисковать при раскрытии собственной информации о стоимости и прибыли, необходимой для расчета упущенной выгоды. Во-вторых, право на потерянную прибыль обычно труднее установить. Распространение конкуренции и специализированных каналов распределения обеспечивает более широкий доступ к замещающей продукции; таким образом, даже в отсутствие продукции предполагаемого нарушителя на рынке, потребители могут не купить продукт патентообладателя. Присужденный ущерб по претензиям из-за эрозии (снижения) цен почти отсутствуют в последние годы. Причина этого - в стоимости и сложности подобных ценовых анализов.

Нa рис. 2 представлены удельные веса причин расчета размера ущерба, который присуждается за нарушение прав патентообладателя. Поскольку некоторые стороны получили и возмещение ущерба от упущенной выгоды, и разумные роялти, итоговые суммы превышают 100\%.

Сложность количественной оценки потери прибыли или разумных роялти возрастает, когда требуется определение доли продаж продукта, обладающего нарушающими патенты компонентами, в отличие от непатентованных. Этот анализ пропорционального распределения относится и ко многим непатентованным продуктам с патентованными усовершенствованиями. Иски относительно нанесенного ущерба могут потребовать эмпирических данных, чтобы определить ценность запатенто-

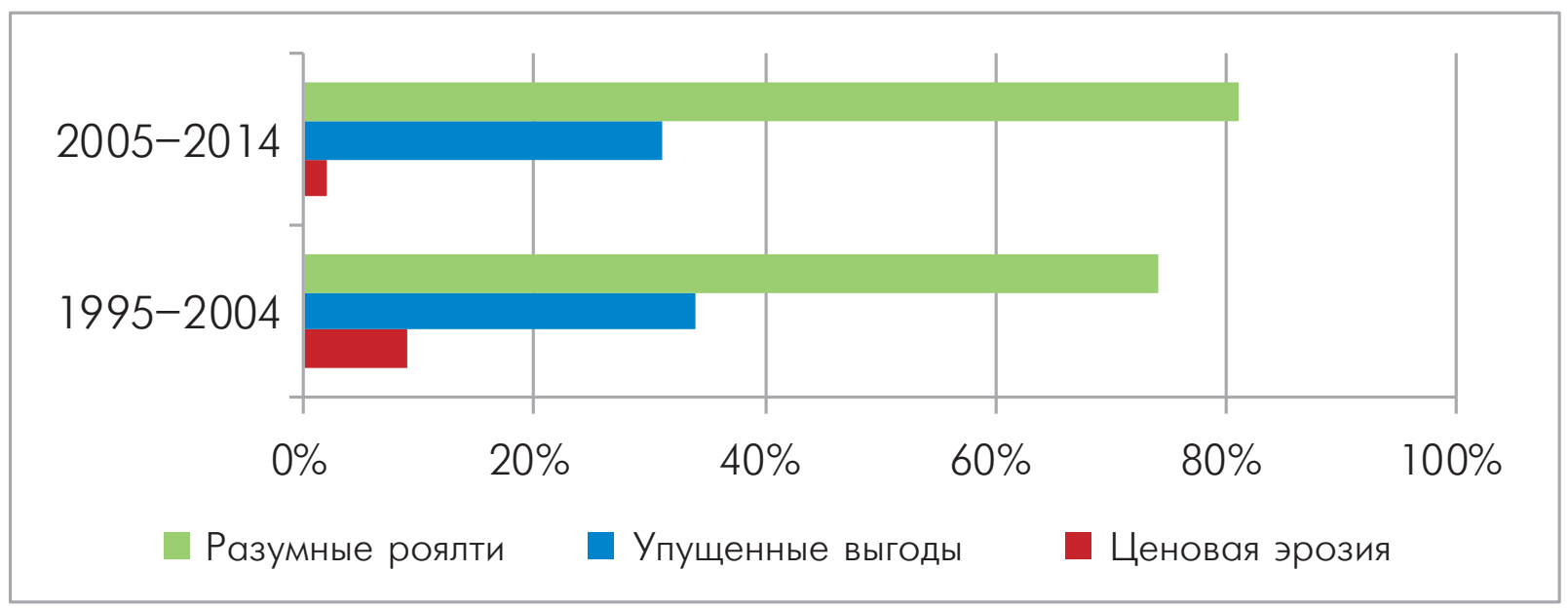

Рис. 2. Структура присужденных ущербов, рассчитанным по причинам ценовой эрозии, упущенной выгоды, разумных роялти

Источник: 2015 Patent Litigation Study: A change in patentee fortunes 
Таблица 2

\section{Средний досудебный период и размер ущерба для практикующих и непрактикующих патентообладателей за период 1995-2014 rr.}

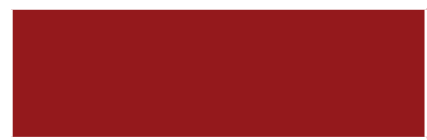

$\mathrm{H} П \mathrm{C}$

Практикующие субъекты

\section{Средний досудебный период (лет)}

ycr

Средняя доля

успешных процессов

(\%)

26

35
Средний размер

присужденного

ущерба (долл.)

9163544

Источник: 2015 Patent Litigation Study: A change in patentee fortunes

ванных компонентов. Для сбора таких данных нужно проводить исследования и статистический анализ потребительского поведения.

Доля успешных процессов для истцов варьирует в зависимости от типа субъекта и стадии решения вопроса. Прежде всего, необходимо отметить, что если им является НПС, то в этом случае нельзя оценить потерянную прибыль.

Как уже указывалось выше, среди НПС участников судебных процессов, можно выделить следующие группы: компании, университеты и индивидуальные заявители. Средний размер назначенного ущерба истцов, относящихся к категории университеты, превосходил размер иска, присужденный компаниям. Однако по требованиям индивидуальных заявителей суды назначали меньше всего (табл. 2).

Средняя сумма присужденного ущерба для разных категорий НПС в 1995-2014 гг. составляла следующие значения:

- НПС - компании - 11,5 млн долл. при $31 \%$ - доля успешных процессов компании в среднем снижается, но все еще остается чуть ниже максимального показателя в $35 \%$.

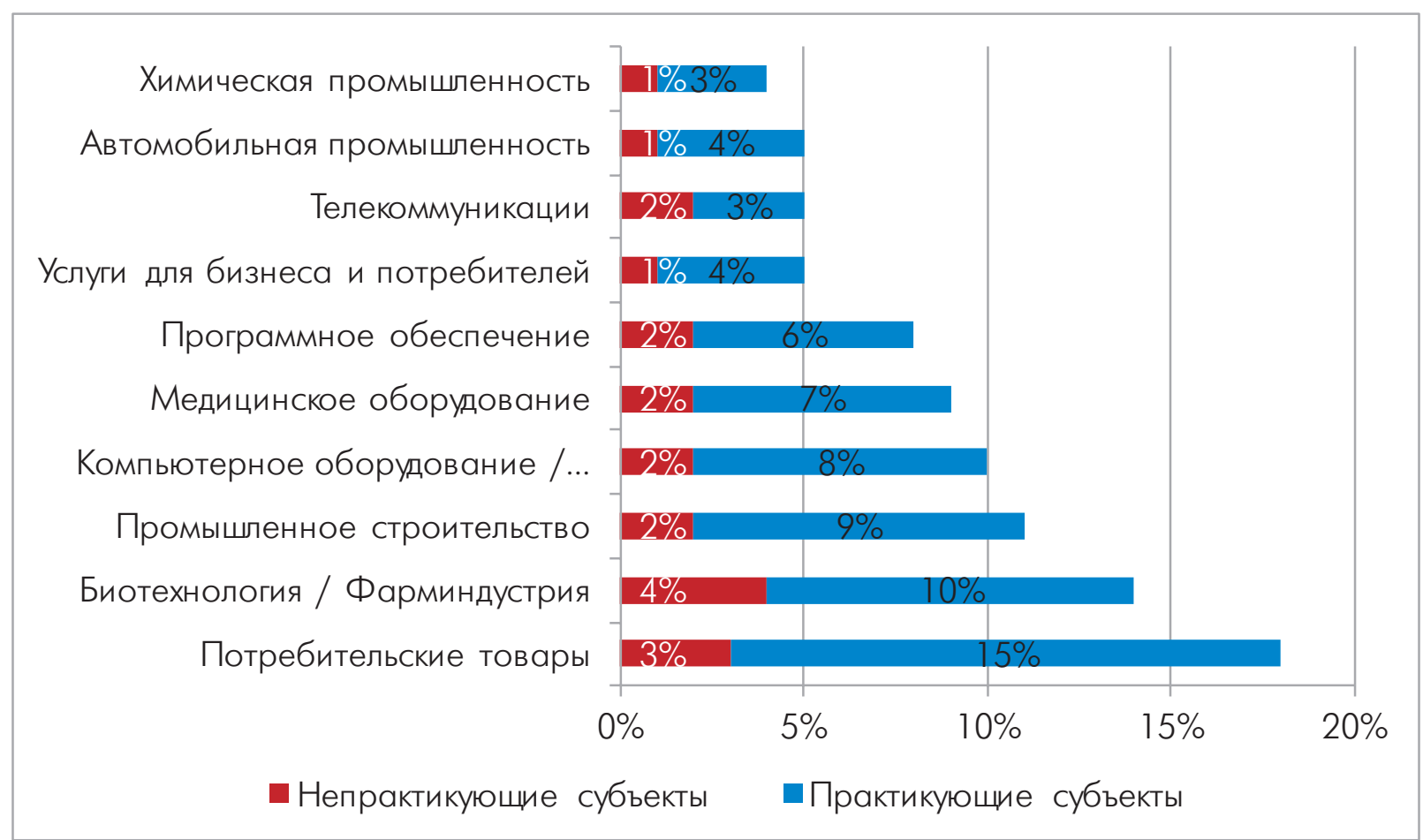

Рис. 3. Вклад в судебные споры топ-10 патентно активных отраслей промышленности, 1995-2014 rr.

Источник: 2015 Patent Litigation Study: A change in patentee fortunes 
- НПС - университеты и некоммерческие организации - 16,2 млн долл. при 48\% доле успешных процессов.

- НПС - индивидуальные заявители - 3 млн долл. при 18\% доле успешных судебных споров.

\section{«ПАТЕНТНЫЙ ТРОЛЛИНГ» В РАЗНЫХ ОТРАСЛЯХ ПРОМЫШЛЕННОСТИ}

Анализ совокупности почти 90\% выявленных охраноспособных технических решений показывает, что они относятся к 10 самых патентно активным отраслям, в т.ч.: потребительские товары, биотехнология/фарминдустрия, промышленное строительство, компьютерное оборудование/электроника, медицинское оборудование, программное обеспечение, услуги для бизнеса и потребителей, телекоммуникации, автомобильная промышленность, химическая промышленность.

В докладе PricewaterhouseCoopers отмечалось, что по разным отраслям промышленно- сти имеются небольшие отличия в средних размерах присужденного ущерба, доли успешных процессов также разнятся (рис. 3 и 4). Средний размер присужденного ущерба для всех отраслей промышленности в целом составляет около 5,4 млн долл.

Патентные судебные дела, связанные с отраслью потребительских товаров, были наиболее распространены в 1995-2014 гг. и составили 18\% от всех принятых решений. Производство потребительских товаров по-прежнему демонстрирует наибольшее число сильных коммерческих и технических решений, с вероятностью успеха, как правило, выше среднего. В то время как процент положительных судебных решений по патентам, связанным с производством потребительских товаров - самый большой, средний размер присужденного ущерба по ним был относительно низким по сравнению с девятью другими наиболее патентно активными отраслями. В 2014 г. по искам о незаконном использовании запатентованных решений,

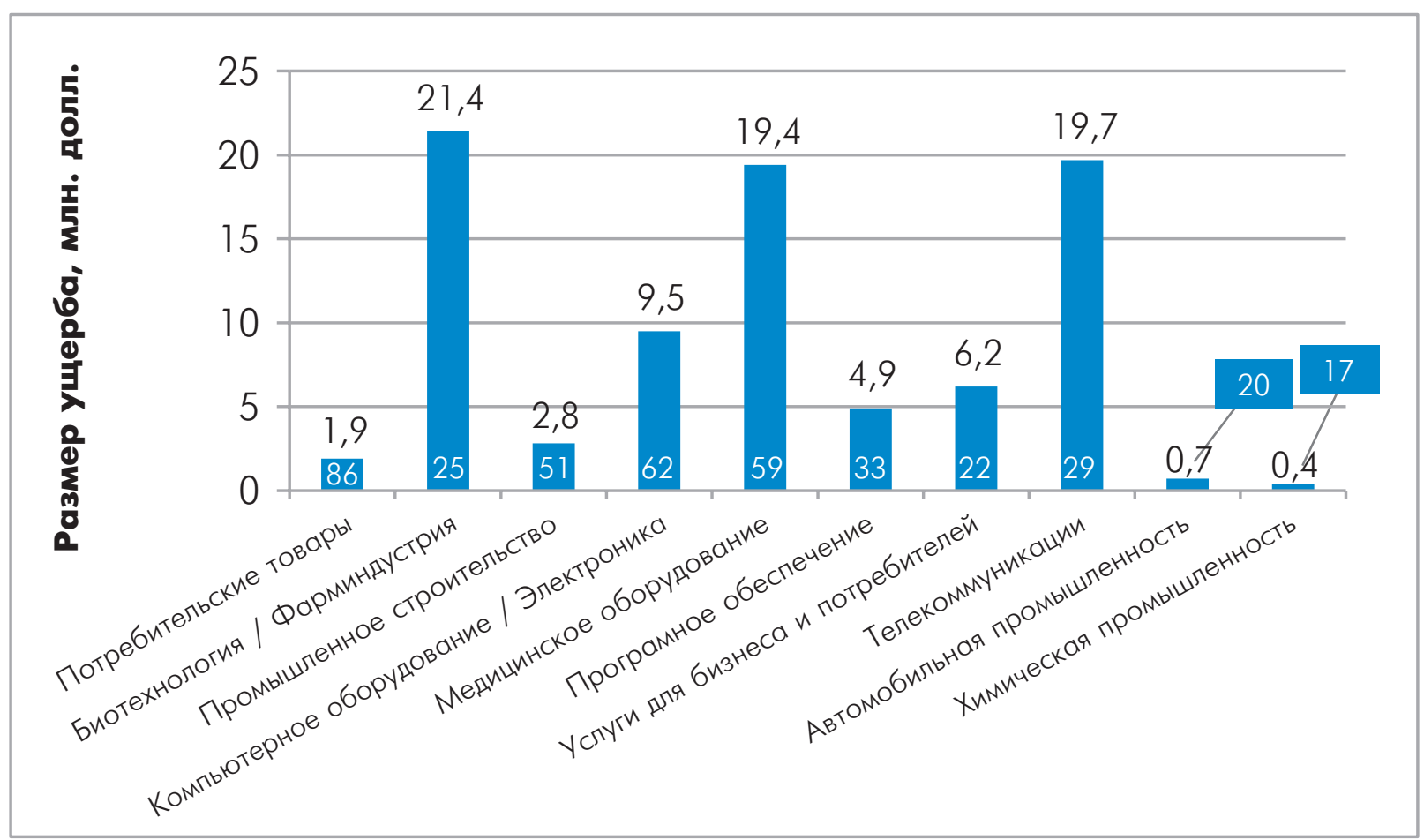

Рис. 4. Средний размер присужденного ущерба для топ-10 патентно активных отраслей промышленности, 1995-2014 rr.

Источник: 2015 Patent Litigation Study: A change in patentee fortunes

Примечание: Число выявленных решений указано в пределах соответствующего столбика 


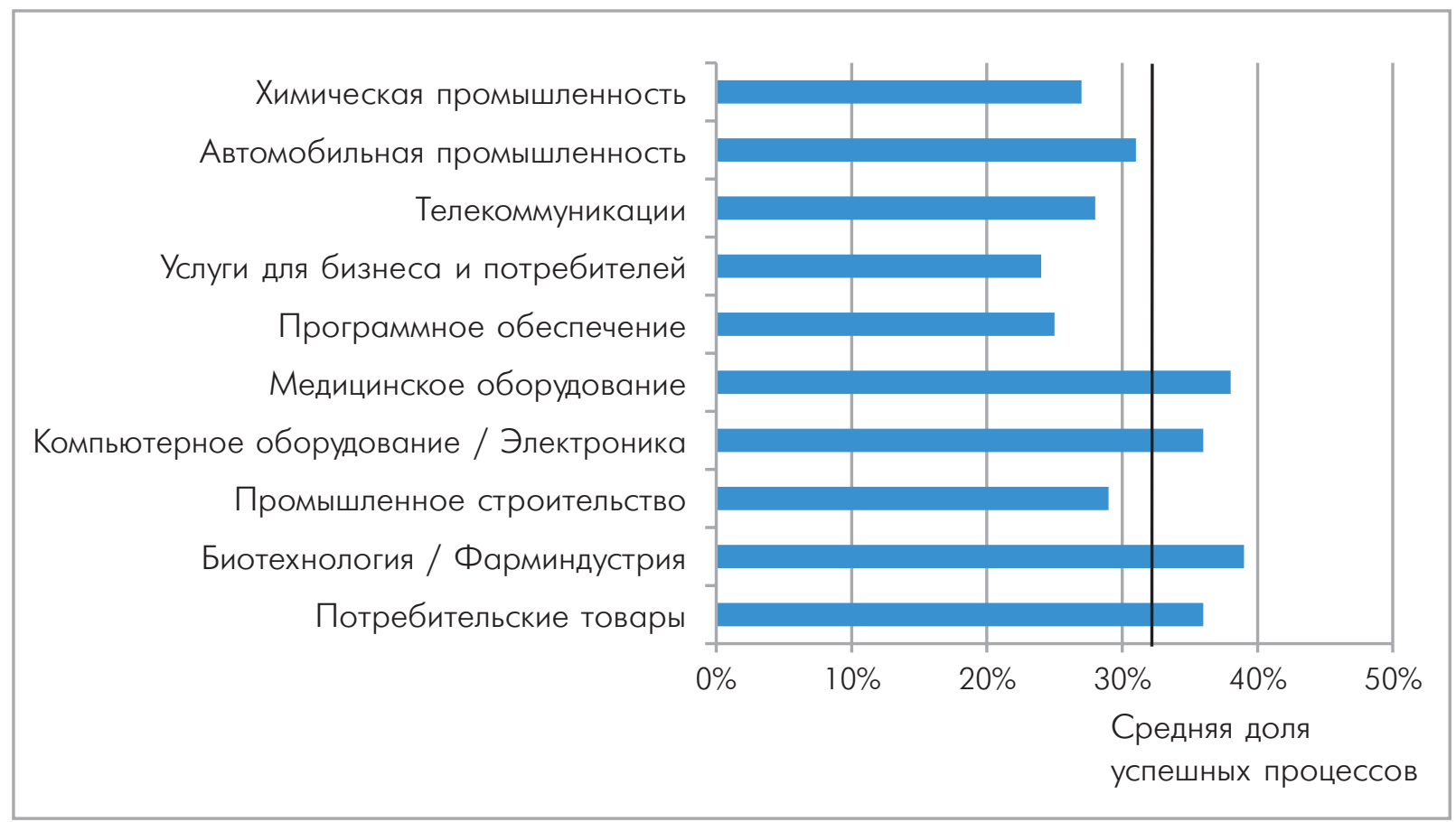

\section{Рис. 5. Доля успешных для патентообладателей процессов в топ-10 отраслей промышленности, 1995-2014 гr.}

Источник: 2015 Patent Litigation Study: A change in patentee fortunes

Примечание: Линия - средняя доля успешных процессов

связанным с биотехнологией/фармацевтикой, телекоммуникациями и медицинским оборудованием были получены значительно более крупные возмещения ущерба, чем в других отраслях.

Отрасли биотехнологии и фарминдустрии имеют самый высокий средний размер присужденного ущерба, за ними следуют телекоммуникации и медицинские приборы.

Общая доля успешных процессов для всех отраслей промышленности в течение 20-летнего периода составляла около 33\%. При этом владельцы патентов, связанных с потребительскими товарами, биотехнологией/ фармацевтикой, медицинскими приборами и компьютерным оборудованием/электронной промышленностью, достигли доли успешных процессов немного выше средней (рис. 5) Доля успешных процессов по всем десяти отраслям была относительно стабильной, отклонение составляло менее 10\% от совокупного для всего исследования показателя (33\%).

\section{ЗАКЛЮЧЕНИЕ}

Обусловленность дальнейшего инновационного развития наличием цивилизованного рынка интеллектуальной собственности давно признана в США, Японии, Германии, затем в середине 1990-х гг. в Китае. Сегодня лидирующие позиции по уровню инновационного развития и участию в мировой торговле интеллектуальной собственностью и занимают страны АТЭС: Китай, США и Япония. Производство высокотехнологичной продукции (товаров, услуг), выход с ней на глобальные рынки, расширение международной интеграции стали для большинства развитых стран важнейшей стратегической моделью и «локомотивом» экономического роста.

Основным показателем эффективного функционирования правовой охраны научно-технических достижений является статистика судебных патентных споров, показывающяа, насколько эффективно работает действующее законодательство об интеллектуальных правах в той или иной стра- 
не. Например, 15 сентября 2016 г. Ведомство по патентам и товарным знакам США (USPTO) зарегистрировало заявку на патент (№ 20160264304) компании Apple на бумажный пакет, поданную 7 марта 2016 г. В тексте документа подробно описывается знаменитый бумажный пакет, известный покупателям Apple Store по всему миру. Ha основе анализа статистики судебных патентных споров США эксперты уже делают прогнозы судьбы этой заявки [14].

В России же детальной статистики о патентных судебных спорах и вынесенных судебных решениях авторам обнаружить не удалось, несмотря на появление сообщений о «патентном троллинге». Без анализа результатов правоприменительной практики использования патентной системы как ресурса инновационно-технологического развития в России, доступного в открытых источниках, рынок интеллектуальной собственности не заработает.
Остается надеяться, что крупным консалтинговым компаниям в России уже по силам, как это сделала PricewaterhouseCoopers, подготовить аналитические материалы, отвечающие на стоящие перед бизнесом следующие актуальные вопросы:

- по каким объектам патентного права рассматривались судебные дела;

- какие категории истцов и ответчиков из каких отраслей в них участвовали;

- какие экономические параметры принимались во внимание при определении размеров исков;

- какие правовые аспекты учитывались для возбуждения судебных патентных исков.

Пока в обзорах отечественной судебной практики можно найти только анализ спорных правовых вопросов, которые рассматриваются вне их технологического содержания. Этого для развития инновационно-технологического бизнеса явно недостаточно.

\section{ЛИТЕРАТУРА}

1. The Original Patent Troll Returns (2007) Intellectual Property Today. May 8, 2007.

2. Sandburg B. (2001) Trolling for Dollars / The Recorder. July 30, 2001.

3. Lerer L. (2006) Meet the Original Patent Troll / IP Law \& Business. July 20, 2006.

4. Касперский E. (2012) Kill The Troll! / Блог Евгения Касперского, 26 июня 2012. https://eugene. kaspersky.ru/2012/06/26/kill-the-troll.

5. Уголовный кодекс Российской Федерации от 13 июня 1996 г. № 63-Ф3 (редакция От 06 июля 2016 г.) / КонсультантПлюс. http://www.consultant. ru/document/cons_doc_LAW_10699.

6. Калиниченко С.В., Торицын И.В. (1999) Стеклянный сосуд - патент РФ № 2139818. http://www. freepatent.ru/patents/2139818.

7. Зиновьев И. (2010) Похитители патентов // Коммерсанть Деньги. № 6 (761) 15.02.2010.

8. Пашина Е. (2016)«Патентные тролли» и другие проблемы интеллектуальной собственности / Портал Legal.report. https://legal.report/ article/21072016/patentnye-trolli-i-drugieproblemy-intellektualnoj-sobstvennosti.
9. Аналитическая справка по результатам анализа судебной практики по вопросам, связанным с правовой охраной объектов интеллектуальной собственности (2009) / Роспатент. http://www. rupto.ru/about/stat/spravka2009.pdf.

10. 2015 Patent Litigation Study: A change in patentee fortunes (2015) / PricewaterhouseCoopers. http://www.pwc.com/us/en/forensic-services/ publications/patent-litigation-study.html.

11. Bessen J., Meurer M. J. (2012) The direct costs from NPE disputes / Boston University School of law working paper. № 12-34.

12. Гук Н. (2016) Патентные тролли в деле: VirnetX отсудила у Apple \$625 млн / Портал Хабрахабр. https://habrahabr.ru/post/298432.

13. Catherine E. Tucker (2014) The Effect of Patent Litigation and Patent Assertion Entities on Entrepreneurial Activity. http://cdn.arstechnica.net/wpcontent/uploads/2014/06/Tucker-Report-5.16.14.pdf.

14. Korinek M., Whang E.A., Shaffer B.A. (2016) A paper bag is disclosed - United States Patent Application 20160264304 dated 15 September 2016 / USPTO. 


\section{REFERENCES}

1. The Original Patent Troll Returns (2007) Intellectual Property Today. May 8, 2007.

2. Sandburg B. (2001) Trolling for Dollars / The Recorder. July 30, 2001.

3. Lerer L. (2006) Meet the Original Patent Troll / IPLaw \& Business. July 20, 2006.

4. Kaspersky, E. (2012) Kill The Troll! A personal blog of Eugene Kaspersky, 26 Jun 2012. https://eugene. kaspersky.ru/2012/06/26/kill-the-troll.

5. Criminal code of the Russian Federation dated 13 June 1996 № 63-FZ (as amended on 06 July 2016) / http://www.consultant.ru/document/cons_ doc_LAW_10699.

6. Kalinichenko S. V., Toritsyn I. V. (1999) Glass jar patent of the Russian Federation № 2139818. http://www.freepatent.ru/patents/2139818.

7. Zinoviev, I. (2010) the Kidnappers patents // Kommersant Money. No. 6 (761) 15.02.2010.

8. Flank E. (2016) «Patent trolls» and other problems of intellectual proper-STI / Portal Legal. report. https://legal.report/article/21072016/ patentnye-trolli-i-drugieproblemy-intellektualnojsobstvennosti.
9. Analytical report on the results of the analysis of judicial practice on issues related with legal protection of intellectual property (2009) / Rospatent. http://www.rupto.ru/about/stat/spravka2009.pdf.

10. 2015 Patent Litigation Study: A change in patentee fortunes (2015) / PricewaterhouseCoopers. http://www.pwc.com/us/en/forensic-services/ publications/patent-litigation-study.html.

11. Bessen J., Meurer M. J. (2012) The direct costs from NPE disputes / Boston University School of law working paper. № 12-34.

12. Guk N. (2016) Patent trolls: VirnetX sued Apple for \$625 million / Portal Habrahabr.https://habrahabr. ru/post/298432.

13. Catherine E. Tucker (2014) The Effect of Patent Litigation and Patent Assertion Entities on Entrepreneurial Activity. http://cdn.arstechnica. net/wpcontent/uploads/2014/06/TuckerReport-5.16.14.pdf.

14. Korinek M., Whang E.A., Shaffer B.A. (2016) A paper bag is disclosed - United States Patent Application 20160264304 dated 15 September 2016 / USPTO.

\section{UDC 004.031.4:001}

Shurtakov K. V. «Patent trolls»: the analysis of foreign and Russian practices (Directorate of State Scientific and Technical Programmes, Moscow, Russial

I Abstract. Presents an analysis of foreign practice of identifying and combating «patent trolling» as a new kind I of business based on the abuse of patent rights. The economic parameters that determine the size of the excited I claims and industry features of «patent trolling».

I Keywords: patent trolls, patent litigation, the amount of lawsuits, patent branch activity.

DOI 10.22394/2410-132X-2016-2-4-293-303 